\title{
Sulfur-, nitrogen- and platinum-doped titania thin films with high catalytic efficiency under visible-light illumination
}

\author{
Boštjan Žener ${ }^{1}$, Lev Matoh ${ }^{1}$, Giorgio Carraro $^{2}$, Bojan Miljević ${ }^{3}$ \\ and Romana Cerc Korošec ${ }^{* 1}$
}

Open Access

\author{
Full Research Paper \\ Address: \\ ${ }^{1}$ Faculty of Chemistry and Chemical Technology, University of \\ Ljubljana, Večna pot 113, 1000 Ljubljana, Slovenia, ${ }^{2}$ Department of \\ Chemical Sciences, University of Padova, Via Francesco Marzolo 1, \\ 35131 Padova, Italy, and ${ }^{3}$ University of Novi Sad, Faculty of \\ Technology, Bulevar cara Lazara 1, 21000 Novi Sad, Serbia \\ Email: \\ Romana Cerc Korošec ${ }^{*}$ - romana.cerc-korosec@fkkt.uni-lj.si \\ * Corresponding author \\ Keywords: \\ doping; photocatalysis; sol-gel synthesis; thin films; titanium dioxide; \\ visible-light illumination
}

Beilstein J. Nanotechnol. 2018, 9, 1629-1640. doi:10.3762/bjnano.9.155

Received: 18 February 2018

Accepted: 03 May 2018

Published: 04 June 2018

Associate Editor: R. Xu

(c) 2018 Žener et al.; licensee Beilstein-Institut. License and terms: see end of document.

\begin{abstract}
Titanium dioxide photocatalysts have received a lot of attention during the past decades due to their ability to degrade various organic pollutants to $\mathrm{CO}_{2}$ and $\mathrm{H}_{2} \mathrm{O}$, which makes them suitable for use in environmental related fields such as air and water treatment and self-cleaning surfaces. In this work, titania thin films and powders were prepared by a particulate sol-gel route, using titanium tetrachloride $\left(\mathrm{TiCl}_{4}\right)$ as a precursor. Afterwards, the prepared sols were doped with nitrogen (ammonium nitrate, urea), sulfur (thiourea) and platinum (chloroplatinic acid), coated onto glass substrates by dip-coating, and thermally treated in a muffle furnace to promote crystallization. The resulting thin films were then characterized by various techniques (i.e., TGA-DSC-MS, XRD, BET, XPS, SEM, band gap measurements). The photocatalytic activity of the prepared thin films was determined by measuring the degradation rate of plasmocorinth $\mathrm{B}(\mathrm{PB})$, an organic pigment used in the textile industry, which can pose an environmental risk when expelled into wastewater. A kinetic model for adsorption and subsequent degradation was used to fit the experimental data. The results have shown an increase in photocatalytic activity under visible-light illumination of nonmetal and metal doped and co-doped titania thin films compared to an undoped sample.
\end{abstract}

\section{Introduction}

In recent years, titanium dioxide $\left(\mathrm{TiO}_{2}\right)$ has emerged as one of the most widely investigated semiconductors [1]. Due to its favorable properties (e.g., chemical and biological stability, nontoxicity and inexpensive price) it is used in a variety of applications, such as photovoltaics [2], white pigments [3], elec- trochemistry [4], catalytic support [5], and most notably, photocatalysis [6]. Photocatalysis is used to describe a process during which a semiconductor (titanium dioxide) interacts with light to produce reactive oxidizing species, which then oxidize adsorbed pollutants, forming $\mathrm{CO}_{2}$ and $\mathrm{H}_{2} \mathrm{O}$ as final products [7]. Because 
of this particularly beneficial characteristic, together with its low-cost and lack of secondary emissions [8], significant research has been focused on the use of $\mathrm{TiO}_{2}$ photocatalysis in various environmental applications, such as water treatment [9-11] and air purification [12].

One of the important factors affecting the photocatalytic activity of $\mathrm{TiO}_{2}$ is its specific surface area. By increasing the specific surface area (porosity) of $\mathrm{TiO}_{2}$, the photocatalytic activity can be increased. One of the ways to increase the porosity of the material is the addition of an organic polymer. After polymer decomposition via thermal treatment, mesoporous materials with high surface area and pore volume are obtained [13-15]. The increase in surface area depends on the type of polymer added, the type of oxides and on the stage of synthesis during which the polymer is added [16-18]. The specific surface area can also be increased by decreasing the particle size of $\mathrm{TiO}_{2}$; however, it has been shown that the photocatalytic activity does not monotonically increase with decreasing particle size, but rather there exists an optimal particle size for pure nanocrystalline $\mathrm{TiO}_{2}$ [19]. This is due to surface recombination of electron-hole pairs in samples with particle sizes smaller than $6 \mathrm{~nm}$.

One of the main drawbacks of using $\mathrm{TiO}_{2}$ as a photocatalyst is the width of its band gap $(3.2 \mathrm{eV})$, which means the electrons can be excited into the conduction band when illuminated by UV light with wavelengths lower than $380 \mathrm{~nm}$ [20-22]. Since the solar-light spectrum contains only around $4 \%$ of UV light, $\mathrm{TiO}_{2}$ is not efficient under solar-light illumination. Different studies have been performed to increase its photocatalytic activity under a broader solar spectrum: doping with metals [23-26], nonmetals [27-30] and co-doping [31,32]. When doping with metals, they act as a free electron trap and thereby prevent electron-hole recombination, which results in enhanced photocatalytic activity of the material system $[33,34]$.

Nitrogen has been shown to be an effective doping element in increasing the response of $\mathrm{TiO}_{2}$ during visible-light illumination. When the material is doped with nitrogen, a linear combination of $2 \mathrm{p}$ orbitals of $\mathrm{N}$ and $\mathrm{O}$ results in the formation of hybrid orbitals, causing a narrowing of the band gap by introducing a new energy level close to the valence band. Nitrogen doping can also create impurity energy levels above the valence band, thus effectively also narrowing the band gap [35,36]. Illumination with visible light can then excite electrons from impurity energy levels into the conduction band.

Sulfur doping has also been shown to enhance the photocatalytic activity under visible-light illumination. Sulfur can be doped as an anion $\left(\mathrm{S}^{2-}\right)$, replacing oxygen, or as a cation $\left(\mathrm{S}^{6+}\right)$, thus replacing titanium $[37,38]$. Substitutional doping of sulfur in
$\mathrm{TiO}_{2}$ narrows the band gap by the linear combination of the $3 p$ orbitals of $\mathrm{S}$ and the $2 p$ orbitals of $\mathrm{O}[39,40]$. In this case, the crystal lattice of $\mathrm{TiO}_{2}$ becomes distorted due to the larger ionic radius of $\mathrm{S}^{2-}$ compared to $\mathrm{O}^{2-}$.

Among all of the approaches to preparation of titania thin films, the sol-gel method is the most versatile, due to its simplicity, cost-effectiveness and low-temperature synthesis. The resulting product is a material with high homogeneity and controllable morphology $[8,41,42]$. During the sol-gel process, initial hydrolysis of the precursor (e.g., titanium tetrachloride, titanium alkoxides) is followed by polycondensation of the hydroxide monomers, during which $-\mathrm{O}-$ and $-\mathrm{OH}-$ bridges are established between metallic atoms, resulting in the formation of an oxide and hydroxide network [43].

The aim of this study was to prepare nonmetal and metal-doped as well as co-doped titania thin films, which are photocatalytically active under visible-light illumination. The photocatalytic activity of our samples was determined by measuring the degradation rate of plasmocorinth $\mathrm{B}$ (PB), an organic pigment belonging to the group of azo dyes. Azo dyes are used in the textile industry as textile colorants and are stable under normal conditions. They have been shown to damage ecosystems when expelled into water systems, and pose very serious health risks to humans, because they can form aromatic amines, which are potentially carcinogenic substances. Furthermore, when the excess dye is expelled into wastewater after the coloring processes, the water becomes colored, thus decreasing light penetration and consequently decreasing photosynthetic activity of organisms in wastewater [44].

The sols prepared in this work were deposited onto object glass substrates by dip-coating. The immobilization of $\mathrm{TiO}_{2}$ in the form of a thin film significantly reduces some of the drawbacks of the practical application of heterogeneous photocatalysis; for instance, the need to separate the photocatalyst from the suspension after the photocatalytic reaction, or the tendency of the particles to agglomerate in aqueous dispersions [45]. The prepared samples were analyzed using thermogravimetric analysis-differential scanning calorimetry-mass spectrometry (TGA-DSCMS), X-ray diffraction spectroscopy (XRD), specific surface area measurements via Brunauer-Emmett-Teller method (BET), X-ray photoelectron spectroscopy (XPS), scanning electron microscopy (SEM), UV-vis spectroscopy and band gap measurements.

\section{Results and Discussion}

Titania thin films were prepared by a particulate sol-gel synthesis, using titanium tetrachloride $\left(\mathrm{TiCl}_{4}\right)$ as a precursor. During the synthesis, different quantities hydrochloric or sulfuric acid 
were added. Afterwards, sources of metal and nonmetal dopants and hydroxypropyl cellulose were added. Table 1 shows sample labels, types and amounts of added dopants, thermal treatment temperatures and calculated crystallite sizes for different samples. The measured atomic percentages of dopants were determined by XPS measurements. The platinum in sample S3_N0.5+0.015 M Pt was added as the final layer in the form of chloroplatinic acid by dip-coating. The last number describes molar concentrations of the deposited solution.

\section{Thermal analysis}

The purpose of thermal analysis measurements (TGA-DSCMS) was to determine the crystallization temperature of different xerogel samples and the course of their thermal decomposition. The thermal decomposition of the amorphous xerogels, followed by the complementary techniques of thermal analysis of different samples are shown in Figure 1.
The thermal decomposition of sample REF occurs in three successive, not well-defined steps. In the first step $\left(30-142{ }^{\circ} \mathrm{C}\right)$, water $(m / z=18)$ evolves from the sample, whereas during the second $\left(142-296{ }^{\circ} \mathrm{C}\right)$ and third $\left(297-500{ }^{\circ} \mathrm{C}\right)$ steps, chloride ions (most probably in the form of hydrogen chloride $(m / z=35))$ evolve. Furthermore, carbon dioxide $(m / z=44)$ also evolved from the sample in the third step. Exothermic peaks in the DSC curve from $\approx 300{ }^{\circ} \mathrm{C}$ onward are due to the process of crystallization of the sample. Around $450{ }^{\circ} \mathrm{C}$, the mass loss and exothermic processes are completed, meaning that the final oxide material is formed. Based on these results and the results of XRD measurements, we determined $450{ }^{\circ} \mathrm{C}$ to be the optimal temperature for the thermal treatment of samples synthesized with $\mathrm{HCl}$.

The thermal decomposition of sample $\mathrm{S} 1$ also occurs in three successive steps. In the first $\left(30-230^{\circ} \mathrm{C}\right)$ and second

Table 1: Sample labels, types and amounts of added dopants, thermal treatment temperatures and calculated crystallite sizes for different samples.

\begin{tabular}{|c|c|c|c|c|c|c|}
\hline Sample name & $\begin{array}{l}\text { Dopant; dopant source; } \\
\text { amount of added dopant }\end{array}$ & $\begin{array}{l}\text { Nominal } \\
\text { amount of } \\
\text { dopant relative } \\
\text { to } \mathrm{TiO}_{2} \\
\text { (atom \%) }\end{array}$ & $\begin{array}{l}\text { Measured } \\
\text { amount } \\
\text { (atom \%) and } \\
\text { type of dopant }\end{array}$ & $\begin{array}{l}\text { Amount } \\
(\mathrm{mL}) \text { and } \\
\text { type of acid } \\
\text { added }\end{array}$ & $\begin{array}{l}\text { Thermal } \\
\text { treatment } \\
\text { temperature } \\
\left({ }^{\circ} \mathrm{C}\right)\end{array}$ & $\begin{array}{l}\text { Calculated } \\
\text { crystallite } \\
\text { size }(\mathrm{nm})\end{array}$ \\
\hline REF & - & - & - & $18 \mathrm{HCl}$ & 450 & 39 \\
\hline Urea_5 & $\mathrm{N}$; urea; $15.699 \mathrm{mg}$ & 5 & - & $18 \mathrm{HCl}$ & 450 & 39 \\
\hline Urea_10 & $\mathrm{N} ;$ urea; $32.658 \mathrm{mg}$ & 10 & - & $18 \mathrm{HCl}$ & 450 & 50 \\
\hline Urea_15 & $\mathrm{N} ;$ urea; $66.060 \mathrm{mg}$ & 15 & $\mathrm{~N} ; 1$ & $18 \mathrm{HCl}$ & 450 & 41 \\
\hline Urea_20 & $\mathrm{N}$; urea; $112.605 \mathrm{mg}$ & 20 & - & $18 \mathrm{HCl}$ & 450 & 50 \\
\hline Thiourea_5 & S; thiourea; $19.668 \mathrm{mg}$ & 5 & - & $18 \mathrm{HCl}$ & 450 & 43 \\
\hline Thiourea_10 & $\mathrm{S}$; thiourea; $41.329 \mathrm{mg}$ & 10 & - & $18 \mathrm{HCl}$ & 450 & 50 \\
\hline Thiourea_15 & $\mathrm{S}$; thiourea; $83.721 \mathrm{mg}$ & 15 & $\mathrm{~S} ; 1$ & $18 \mathrm{HCl}$ & 450 & 60 \\
\hline Thiourea_20 & $\mathrm{S}$; thiourea; $142.37 \mathrm{mg}$ & 20 & - & $18 \mathrm{HCl}$ & 450 & 46 \\
\hline S1 & $\mathrm{S} ; \mathrm{H}_{2} \mathrm{SO}_{4} ; 1.65 \mathrm{~mL}(c=12 \mathrm{M})$ & - & - & $1.65 \mathrm{H}_{2} \mathrm{SO}_{4}$ & 600 & 18 \\
\hline S2 & $\mathrm{S} ; \mathrm{H}_{2} \mathrm{SO}_{4} ; 3.3 \mathrm{~mL}(c=12 \mathrm{M})$ & - & - & $3.3 \mathrm{H}_{2} \mathrm{SO}_{4}$ & 600 & 10 \\
\hline S3 & $\mathrm{S} ; \mathrm{H}_{2} \mathrm{SO}_{4} ; 4.95 \mathrm{~mL}(c=12 \mathrm{M})$ & - & 1 & $4.95 \mathrm{H}_{2} \mathrm{SO}_{4}$ & 600 & 10 \\
\hline S4 & $\mathrm{S} ; \mathrm{H}_{2} \mathrm{SO}_{4} ; 6.6 \mathrm{~mL}(c=12 \mathrm{M})$ & - & - & $6.6 \mathrm{H}_{2} \mathrm{SO}_{4}$ & 600 & 11 \\
\hline S5 & $\mathrm{S} ; \mathrm{H}_{2} \mathrm{SO}_{4} ; 8.25 \mathrm{~mL}(c=12 \mathrm{M})$ & - & - & $8.25 \mathrm{H}_{2} \mathrm{SO}_{4}$ & 600 & 12 \\
\hline S3_N0.5 & $\begin{array}{l}\mathrm{S} ; \mathrm{H}_{2} \mathrm{SO}_{4} ; 4.95 \mathrm{~mL}(c=12 \mathrm{M}) \\
\mathrm{N} ; \mathrm{NH}_{4} \mathrm{NO}_{3} ; 13.765 \mathrm{mg}\end{array}$ & $\overline{0} \cdot 5$ & $\begin{array}{l}\mathrm{S} ; 1 \\
\mathrm{~N} ; 1\end{array}$ & $3.3 \mathrm{H}_{2} \mathrm{SO}_{4}$ & 600 & 8 \\
\hline S3_N1 & $\begin{array}{l}\mathrm{S} ; \mathrm{H}_{2} \mathrm{SO}_{4} ; 4.95 \mathrm{~mL}(c=12 \mathrm{M}) \\
\mathrm{N} ; \mathrm{NH}_{4} \mathrm{NO}_{3} ; 27.679 \mathrm{mg}\end{array}$ & $\overline{1}$ & -- & $3.3 \mathrm{H}_{2} \mathrm{SO}_{4}$ & 600 & 10 \\
\hline S3_N2 & $\begin{array}{l}\mathrm{S} ; \mathrm{H}_{2} \mathrm{SO}_{4} ; 4.95 \mathrm{~mL}(c=12 \mathrm{M}) \\
\mathrm{N} ; \mathrm{NH}_{4} \mathrm{NO}_{3} ; 54.816 \mathrm{mg}\end{array}$ & $\overline{2}$ & -- & $3.3 \mathrm{H}_{2} \mathrm{SO}_{4}$ & 600 & 8 \\
\hline S3_N4 & $\begin{array}{l}\mathrm{S} ; \mathrm{H}_{2} \mathrm{SO}_{4} ; 4.95 \mathrm{~mL}(c=12 \mathrm{M}) \\
\mathrm{N} ; \mathrm{NH}_{4} \mathrm{NO}_{3} ; 109.658 \mathrm{mg}\end{array}$ & $\overline{4}$ & -- & $3.3 \mathrm{H}_{2} \mathrm{SO}_{4}$ & 600 & 8 \\
\hline S3_N6 & $\begin{array}{l}\mathrm{S} ; \mathrm{H}_{2} \mathrm{SO}_{4} ; 4.95 \mathrm{~mL}(c=12 \mathrm{M}) \\
\mathrm{N} ; \mathrm{NH}_{4} \mathrm{NO}_{3} ; 164.542 \mathrm{mg}\end{array}$ & $\overline{6}$ & -- & $3.3 \mathrm{H}_{2} \mathrm{SO}_{4}$ & 600 & 9 \\
\hline S3_N0.5+1\% Pt & $\begin{array}{l}\mathrm{S} ; \mathrm{H}_{2} \mathrm{SO}_{4} ; 4.95 \mathrm{~mL}(c=12 \mathrm{M}) \\
\mathrm{N} ; \mathrm{NH}_{4} \mathrm{NO}_{3} ; 13.765 \mathrm{mg} ; \mathrm{Pt} \\
\mathrm{H}_{2} \mathrm{PtCl}_{6} ; 290 \mu \mathrm{L}(c=0.344 \mathrm{M})\end{array}$ & $\begin{array}{l}- \\
0.5 \\
1\end{array}$ & $\begin{array}{l}\mathrm{S} ; 1 \\
\mathrm{~N} ; 1 \\
\mathrm{Pt} ; 0.5\end{array}$ & $3.3 \mathrm{H}_{2} \mathrm{SO}_{4}$ & 600 & 8 \\
\hline S3_N0.5+0.015 M Pt & $\begin{array}{l}\mathrm{S} ; \mathrm{H}_{2} \mathrm{SO}_{4} ; 4.95 \mathrm{~mL}(c=12 \mathrm{M}) \\
\mathrm{N} ; \mathrm{NH}_{4} \mathrm{NO}_{3} ; 13.765 \mathrm{mg} ; \mathrm{Pt} \\
\mathrm{H}_{2} \mathrm{PtCl}_{6} ; 0.015 \mathrm{M}\end{array}$ & $\overline{0} .5$ & -- & $3.3 \mathrm{H}_{2} \mathrm{SO}_{4}$ & 600 & - \\
\hline
\end{tabular}



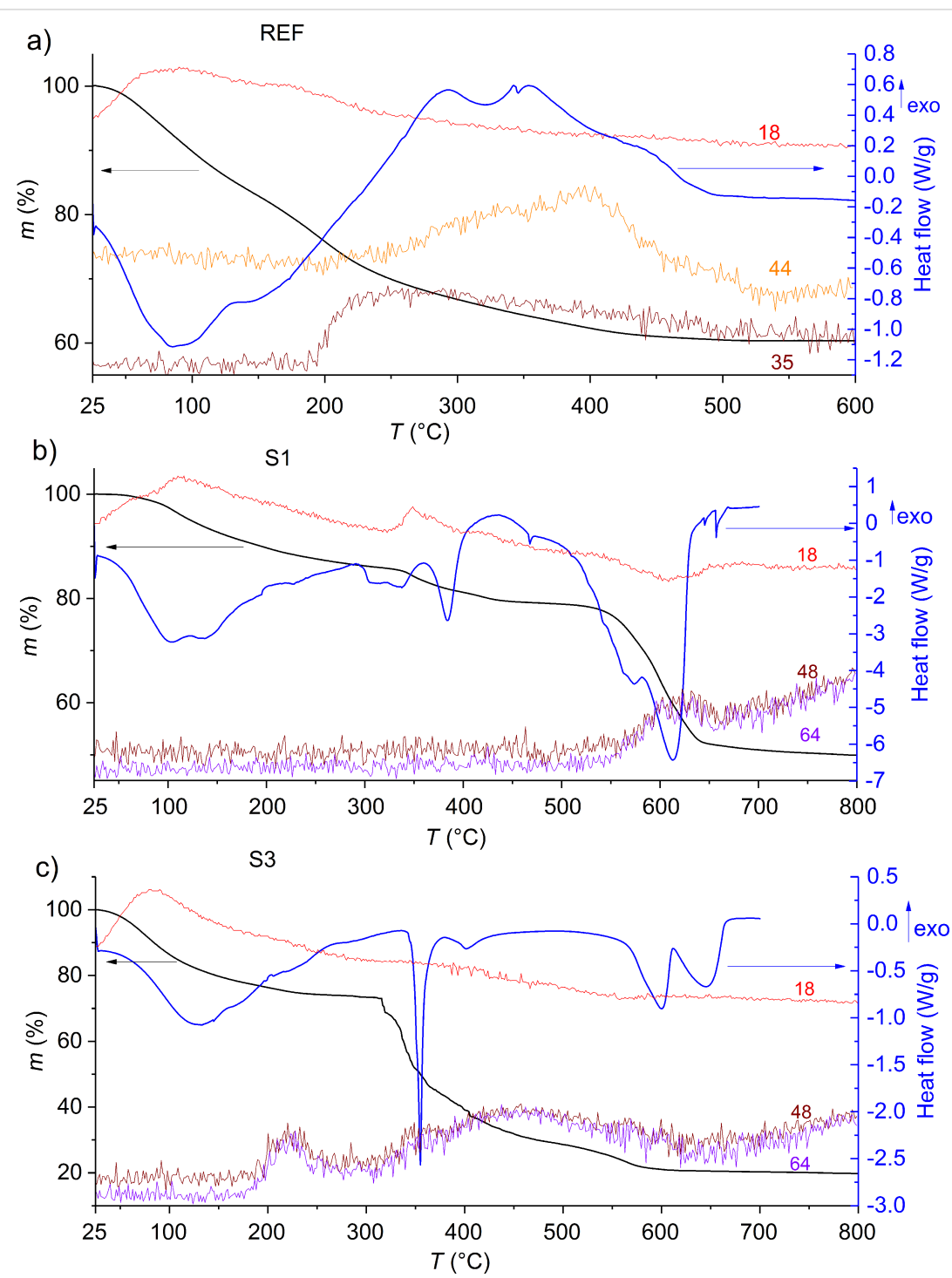

Figure 1: Thermogravimetric analysis-differential scanning calorimetry-mass spectrometry (TGA-DSC-MS) curves of different xerogel samples: a) REF, b) S1 and c) S3.

$\left(330-440{ }^{\circ} \mathrm{C}\right)$ step, water $(m / z=18)$ evolves, whereas in the third $\left(510-560{ }^{\circ} \mathrm{C}\right)$ step, sulfur oxides $(\mathrm{m} / \mathrm{z}=48$ and 64$)$ evolve. Exothermic peaks, due to to the process of crystallization are overlapped by endothermic peaks, originating from the evolution of sulfates. Based on these results and the results of XRD measurements, $600{ }^{\circ} \mathrm{C}$ was determined to be the optimal temperature for the thermal treatment of samples synthesized with $\mathrm{H}_{2} \mathrm{SO}_{4}$.

The thermal decomposition of sample S3 occurs in three successive steps. In the first step $\left(30-250^{\circ} \mathrm{C}\right)$, water $(m / z=18)$ evolves from the sample, in the second $\left(285-510^{\circ} \mathrm{C}\right)$ and third $\left(510-610^{\circ} \mathrm{C}\right)$ step sulfur oxides $(\mathrm{m} / \mathrm{z}=48$ and 64$)$ evolve from the sample. The exothermic peaks of crystallization are again overlapped by the endothermic peaks due to the evolution of sulfates. Sulfur oxides start evolving from this sample at lower temperatures (compared to S1) due to the presence of excess sulfates that are not bound in the structure of $\mathrm{TiOSO}_{4}$. We attribute this to higher added volumes of $\mathrm{H}_{2} \mathrm{SO}_{4}$ during the synthesis. In the last step, sulfates from the thermal decomposition of $\mathrm{TiOSO}_{4}$ evolve from the sample.

\section{X-ray diffraction}

Typical XRD patterns for selected samples, synthesized with $\mathrm{HCl}$ (thermal treatment at $450{ }^{\circ} \mathrm{C}$ ) or $\mathrm{H}_{2} \mathrm{SO}_{4}$ (thermal treatment at $600{ }^{\circ} \mathrm{C}$ ), $\mathrm{S} 1-\mathrm{S} 5$ and the structural evolution of sample $\mathrm{S} 4$ as a function of thermal treatment temperature are shown in Figure 2. All of the samples have one major peak at $2 \theta \approx 25.3^{\circ}$, which corresponds to the reflections of anatase phase. Some patterns also show peaks at $2 \theta \approx 29^{\circ}$ and $2 \theta \approx 32^{\circ}$, which corre- 
spond to reflections of silicon in the case of very thin films, which do not fully cover the substrate. Anatase is the only polymorphic modification of $\mathrm{TiO}_{2}$ present in the samples.
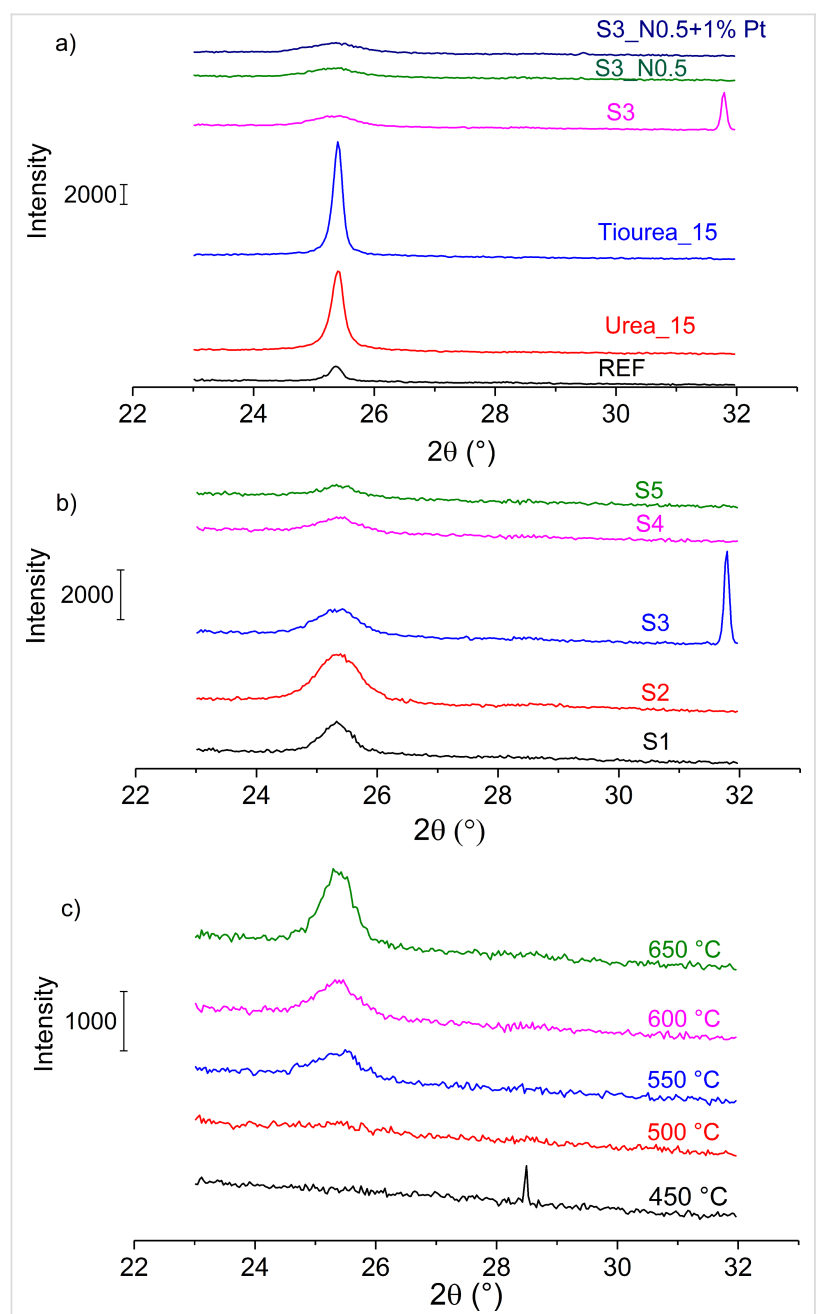

Figure 2: X-ray diffraction patterns for samples a) synthesized with $\mathrm{HCl}, \mathrm{b})$ samples S1-S5, and c) the crystallization process of sample S4.

Table 1 shows the average calculated crystallite size of anatase in the thin films, calculated with Scherrer's formula (Equation 1), for different samples.

$$
L=\frac{K \lambda}{\beta \cos \theta}
$$

In Equation 1, $L$ represents the calculated crystallite size, $K$ is a dimensionless shape factor, $\lambda$ is the $\mathrm{X}$-ray wavelength, $\beta$ is the peak width at half the maximum intensity (FWHM) and $\theta$ is the Bragg angle.

Larger crystallites were found in samples synthesized with $\mathrm{HCl}$ (REF-Thiourea_20, 39-60 nm) compared to samples synthe- sized with $\mathrm{H}_{2} \mathrm{SO}_{4}(\mathrm{~S} 1-\mathrm{S} 5,10-18 \mathrm{~nm})$. The results also show a trend of decreasing crystallite size with increasing volume of $\mathrm{H}_{2} \mathrm{SO}_{4}$ added during the synthesis ( $\mathrm{S} 1-\mathrm{S} 5$ ). We contribute this to the formation of titanium oxysulfate $\left(\mathrm{TiOSO}_{4}\right)$ which inhibits crystallization. The addition of $\mathrm{NH}_{4} \mathrm{NO}_{3}$ also decreases the crystallite size of the samples. The addition of Pt did not have any effect on the crystallite size.

Crystallization of sample S4: Figure 2c shows XRD patterns for sample $\mathrm{S} 4$ at different thermal treatment temperatures. At 450 and $500{ }^{\circ} \mathrm{C}$, the sample has not yet crystallized (amorphous phase present). The sample starts crystallizing at $550{ }^{\circ} \mathrm{C}$ (crystallite size $9 \mathrm{~nm}$ ). With increasing thermal treatment temperature, the crystallite size also increases $\left(11 \mathrm{~nm}\right.$ at $600{ }^{\circ} \mathrm{C}$ and $14 \mathrm{~nm}$ at $\left.650{ }^{\circ} \mathrm{C}\right)$.

\section{Specific surface area (BET)}

Table 2 summarizes the BET specific surface area measured for selected samples. The samples synthesized with $\mathrm{H}_{2} \mathrm{SO}_{4}$ (samples S3-S3_N0.5+1\% Pt) have a higher specific surface than samples synthesized with $\mathrm{HCl}$ (REF-Thiourea_15). We can explain this with the observed decrease in crystallite size, which is typical for samples synthesized with $\mathrm{H}_{2} \mathrm{SO}_{4}(\approx 10 \mathrm{~nm})$ compared to samples synthesized with $\mathrm{HCl}(\approx 50 \mathrm{~nm})$ [19].

\begin{tabular}{|c|c|c|c|}
\hline Sample name & $\begin{array}{l}\text { Surface area } \\
\left(\mathrm{m}^{2} / \mathrm{g}\right)\end{array}$ & $\begin{array}{l}\text { Band gap } \\
(\mathrm{eV})\end{array}$ & $\begin{array}{l}\text { Wavelength } \\
(\mathrm{nm})\end{array}$ \\
\hline REF & 44.1 & 3.44 & 361 \\
\hline Urea_15 & 24.2 & 3.16 & 392 \\
\hline Thiourea_15 & 49.5 & 2.81 & 442 \\
\hline S3 & 80.2 & 3.10 & 400 \\
\hline S3_N0.5 & 84.5 & 3.07 & 403 \\
\hline S3_N0.5+1\% Pt & 83.7 & 3.08 & 403 \\
\hline
\end{tabular}

Figure 3 shows the pore size distribution for a sample synthesized with $\mathrm{HCl}(\mathrm{REF})$ and $\mathrm{H}_{2} \mathrm{SO}_{4}(\mathrm{~S} 3)$. Sample REF has a welldefined uniform pore size distribution $(\approx 10 \mathrm{~nm})$, whereas $\mathrm{S} 3$ has a multimodal pore size distribution. The distributions of pores in other samples synthesized with $\mathrm{HCl}$ (Urea_15, Thiourea_15) and $\mathrm{H}_{2} \mathrm{SO}_{4}\left(\mathrm{~S} 3 \_\mathrm{N} 0.5, \mathrm{~S} 3 \_\mathrm{N} 0.5+1 \% \mathrm{Pt}\right)$ are similar to the distributions shown in Figure 3.

\section{Band gap measurements}

The diffuse reflectance, $R$, of the measured samples as a function of the wavelength $\lambda$ is shown in the Figure $4 a$, and in Figure $4 \mathrm{~b}$, one can see the modified Kubelka-Munk function, $(F(R) h v)^{\mathrm{n}}$, vs energy, $E_{\mathrm{g}}$, where $F$ is the Kubelka-Munk function of the measured diffuse reflectance $R$ as follows: 


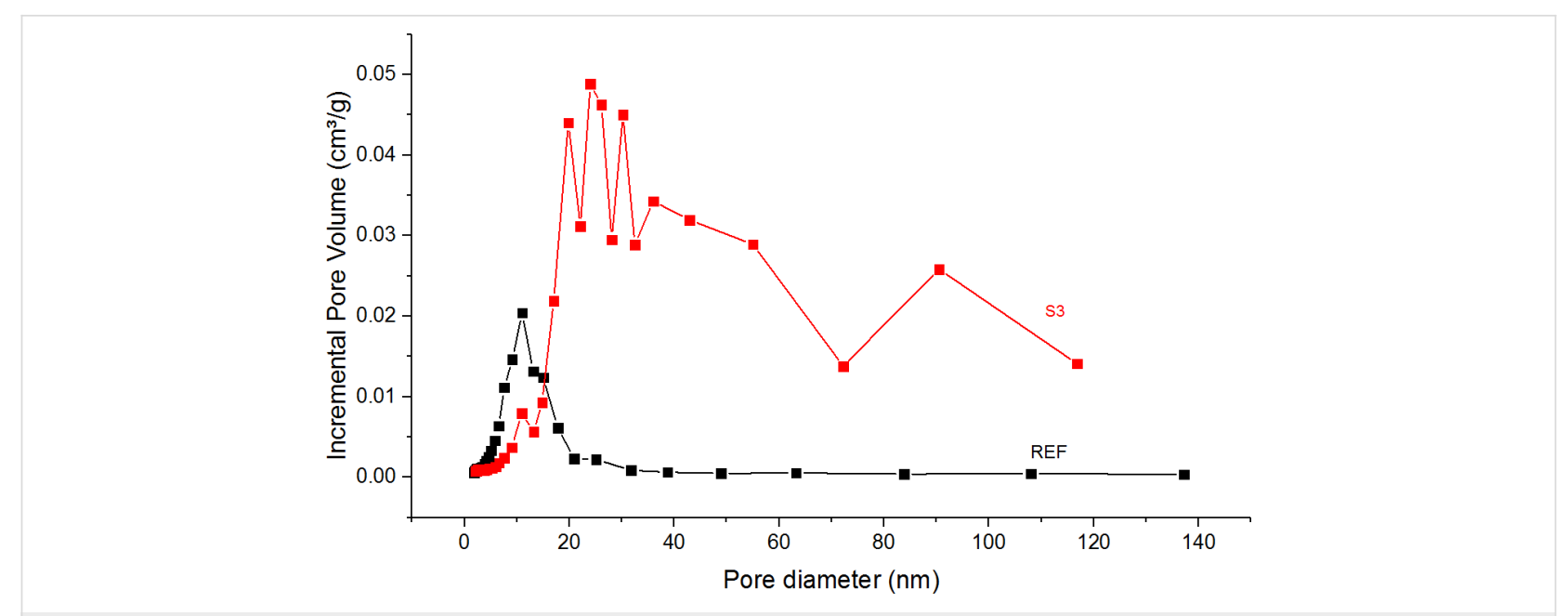

Figure 3: Pore size distribution for samples REF and S3.
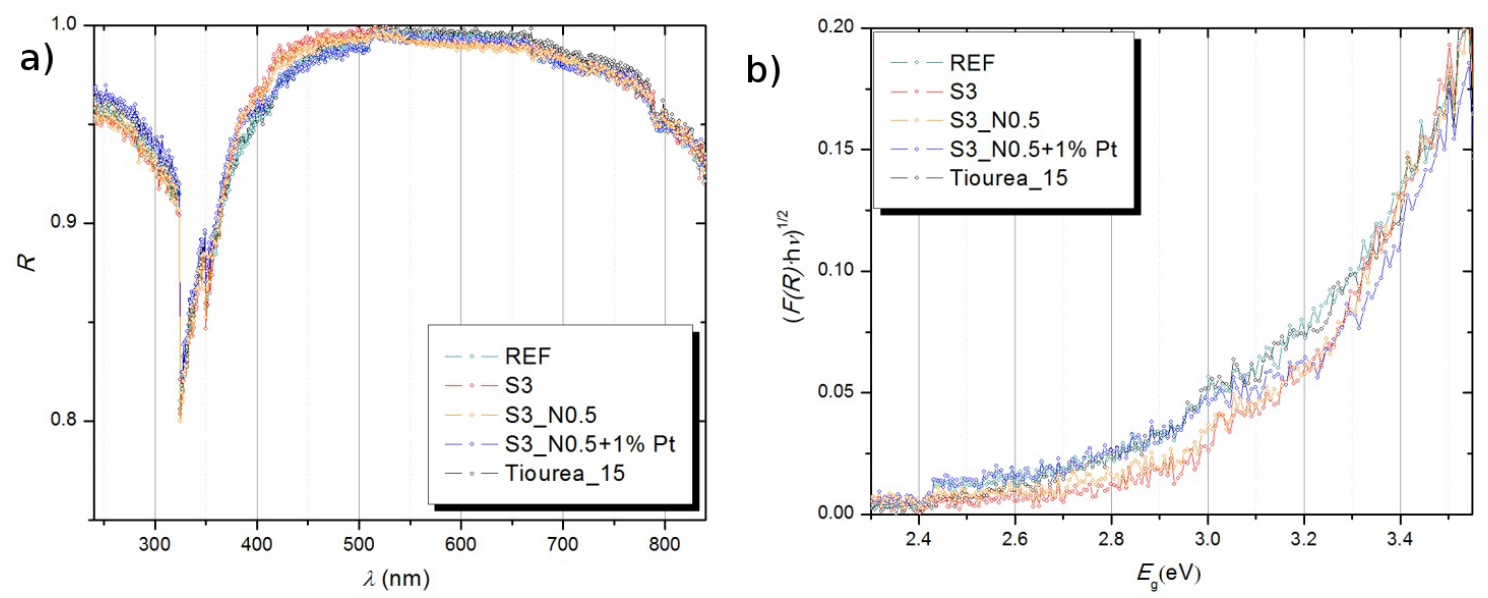

Figure 4: (a) Measured diffuse reflectance plotted as a function of the wavelength $-R(\lambda)$ and (b) modified Kubelka-Munk function vs energy.

$F(R)=(1-R)^{2} / 2 R$. The band gap energy was determined from this plot by extrapolating the linear fit of the straight section to the $(F(R) h v)^{\mathrm{n}}=0$ intercept of the energy coordinate.

Table 2 shows band gap values for selected samples. The results show an expected narrowing of the band gap width for doped samples (Urea_15, Thiourea_15, S3, S3_N0.5 and $\mathrm{S} 3$ N $0.5+1 \% \mathrm{Pt}$ ) relative to the undoped sample (REF). Consequentially, doping $\mathrm{TiO}_{2}$ with $\mathrm{S}$ or $\mathrm{N}$ shifts the absorbance toward visible light, whereas doping with Pt (sample S3_N0.5+1\% Pt) does not additionally narrow the band gap compared to the sample without Pt (S3_N0.5). The band gap narrowing is explained by the creation of new extra states within the band gap created by interstitially doped $\mathrm{N}$ and S [18]. On the other hand, Pt acts as a trap for free electrons and inhibits electron-hole recombination. Doping our reference sample with urea and thiourea has shown to significantly de- crease the band gap width (band gap is $3.44 \mathrm{eV}$ for REF, $3.16 \mathrm{eV}$ for Urea_15 and $2.81 \mathrm{eV}$ for Thiourea_15).

\section{X-ray photoelectron spectroscopy}

XPS measurements were performed on selected samples to determine the amount of dopant present and the oxidation states. XPS spectra for selected samples are presented in Figure 5. The survey spectra of the specimen (not reported) indicate the presence of carbon, oxygen and nitrogen in all the analyzed samples. Irrespective of the synthesis conditions, the $\mathrm{C} 1 \mathrm{~s}$ peak (not reported) is located at $284.8 \mathrm{eV}$, which can be attributed to adventitious surface contamination due to air exposure [46]. All the specimens are characterized by the Ti $2 \mathrm{p}_{3 / 2}$ binding energy (BE) of $458.7 \mathrm{eV}$, as well as the separation between the spin-orbit components $(\Delta(\mathrm{BE})=5.7 \mathrm{eV})$ (Figure 5 top-left) in line with the presence of $\mathrm{Ti}(\mathrm{IV})$ in $\mathrm{TiO}_{2}$ [46]. Regarding the sulfur containing samples (Figure 5, top right panel), the $S 2 p$ 



Figure 5: X-ray photoelectron spectra for selected specimens, reporting the Ti $2 p, S 2 p, N$ 1s and Pt $4 f$ peaks.

XPS peaks located at $168.7 \mathrm{eV}$ with a tailing at higher binding energies could be attributed to $\mathrm{S}(\mathrm{VI})$ species corresponding to the $\mathrm{S}(\mathrm{VI})$ cation in $\mathrm{S}=\mathrm{O}$ and $\mathrm{S}-\mathrm{O}$ bonds, occurring when $\mathrm{Ti}(\mathrm{IV})$ is interstitially replaced by sulfur atoms. In addition, no signal for anionic S species are recorded [46,47]. Irrespective of the synthetic conditions, the analysis of the $\mathrm{N} 1 \mathrm{~s}$ peaks (Figure 5 bottom, left panel) highlights the presence of a component located at $\mathrm{BE}=400.1 \mathrm{eV}$, suggesting the formation of interstitially oxidized nitrogen in $\mathrm{Ti}-\mathrm{O}-\mathrm{N}$ species. The $\mathrm{N} 1 \mathrm{~s}$ signal is characterized by a high signal-to-noise ratio, preventing an unambiguous attribution of the peak tailing at higher/lower energies, which are attributed to the absorption of other nitrogen species [46]. On the other hand, the presence of $\mathrm{Ti}-\mathrm{N}$ bonds can be clearly ruled out $[46,48]$. In the sample S3_N0.5+1\%Pt, the Pt $4 \mathrm{f}_{7 / 2}$ photoelectron peak is centered at $\mathrm{BE}=71.0 \mathrm{eV}$, confirming the presence of elemental Pt [46]. Typical surface concentration values calculated by XPS analyses are 1 atom $\%$ for $\mathrm{S}$ and $\mathrm{N}$, whereas platinum has a concentration of 0.5 atom $\%$.

\section{Scanning electron microscopy}

Figure 6 shows cross-sections of thin films of Urea_15 (Figure 6a) and S4 (Figure 6b). By substituting $\mathrm{HCl}$ (Figure 6a) with $\mathrm{H}_{2} \mathrm{SO}_{4}$ (Figure $6 \mathrm{~b}$ ), we obtained more porous (confirmed by BET measurements) and thicker (thickness is $210 \mathrm{~nm}$ for Urea_15 and $280 \mathrm{~nm}$ for S4) thin films. Figure 5a also shows the formation of $\mathrm{TiO}_{2}$ agglomerates approximately $50 \mathrm{~nm}$ in size, which has also been observed with XRD.

\section{Photocatalytic activity}

Due to the large number of samples prepared, only the results related to samples with optimal photocatalytic activity will be presented here. The photocatalytic activity under visible light was measured by observing the degradation rate of $\mathrm{PB}$, an organic dye. The concentration of $\mathrm{PB}$ at different illumination times was determined by measuring its UV-vis absorbance spectra and calculating using the Beer-Lambert law (Equation 2).

$$
A(\lambda=527 \mathrm{~nm})=\varepsilon \cdot l \cdot c
$$

In this equation, $A$ is the absorbance of the $\mathrm{PB}$ solution at $527 \mathrm{~nm}$ excitation at different illumination times, $c$ is the molar concentration of $\mathrm{PB}$ at different illumination times, $\varepsilon$ is the molar absorptivity coefficient and $l$ is the optical path length. 


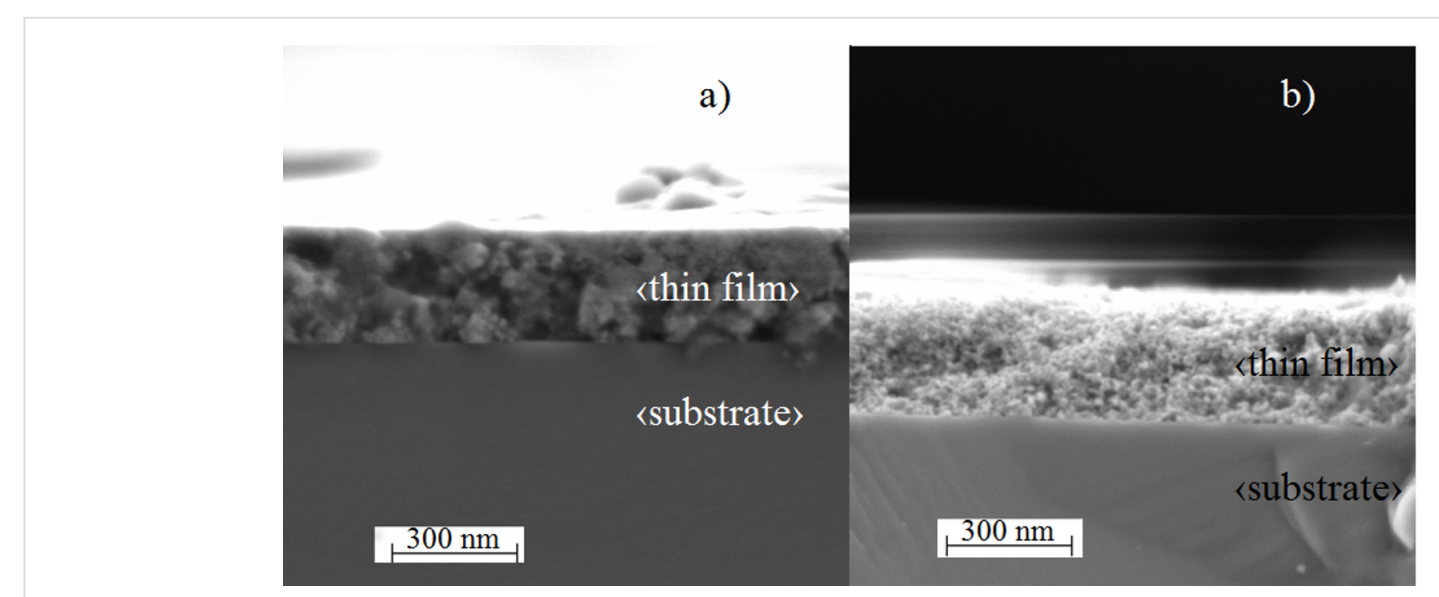

Figure 6: Cross-sections of thin films of samples a) Urea_15 and b) S4.

The results are presented in Figure 7, which show the kinetic results for plasmocorinth $\mathrm{B}(\mathrm{PB})$ degradation for samples synthesized with $\mathrm{HCl}$ (Figure 7a) and synthesized with $\mathrm{H}_{2} \mathrm{SO}_{4}$ (Figure 7b). Different dots represent experimental data (acquired with UV-vis spectroscopy) and lines represent a fitted kinetic model. A kinetic model for adsorption (zero-order rate constant, $k_{0}$ ) and subsequent degradation (first-order rate constant, $k_{1}$ ) was used to fit the experimental data as follows:

$$
\frac{\mathrm{d} c}{\mathrm{~d} t}=-k_{0}-k_{1} c
$$

By solving the differential Equation 3, we get the following model equation describing the dependence of concentration on time:

$$
c=-\frac{k_{0}}{k_{1}}\left(1-e^{-k_{1} t}\right)+c_{0} e^{-k_{1} t},
$$

where $c$ represents the concentration of $\mathrm{PB}$ after a certain time of illumination, $c_{0}$ represents the concentration of $\mathrm{PB}$ before illumination and $t$ is the illumination time.

To separate the processes of adsorption and photocatalysis, two experiments were carried out under dark conditions. The results of these experiments are presented only as data points (filled brown circles) in Figure 7a (Adsorption REF) and Figure 7b (Adsorption S3). We observed only a small decrease in the concentration of $\mathrm{PB}$ due to adsorption.

Figure 8 shows the first-order rate constants $\left(k_{1}\right)$ for PB degradation calculated using the model presented in Equation 4,
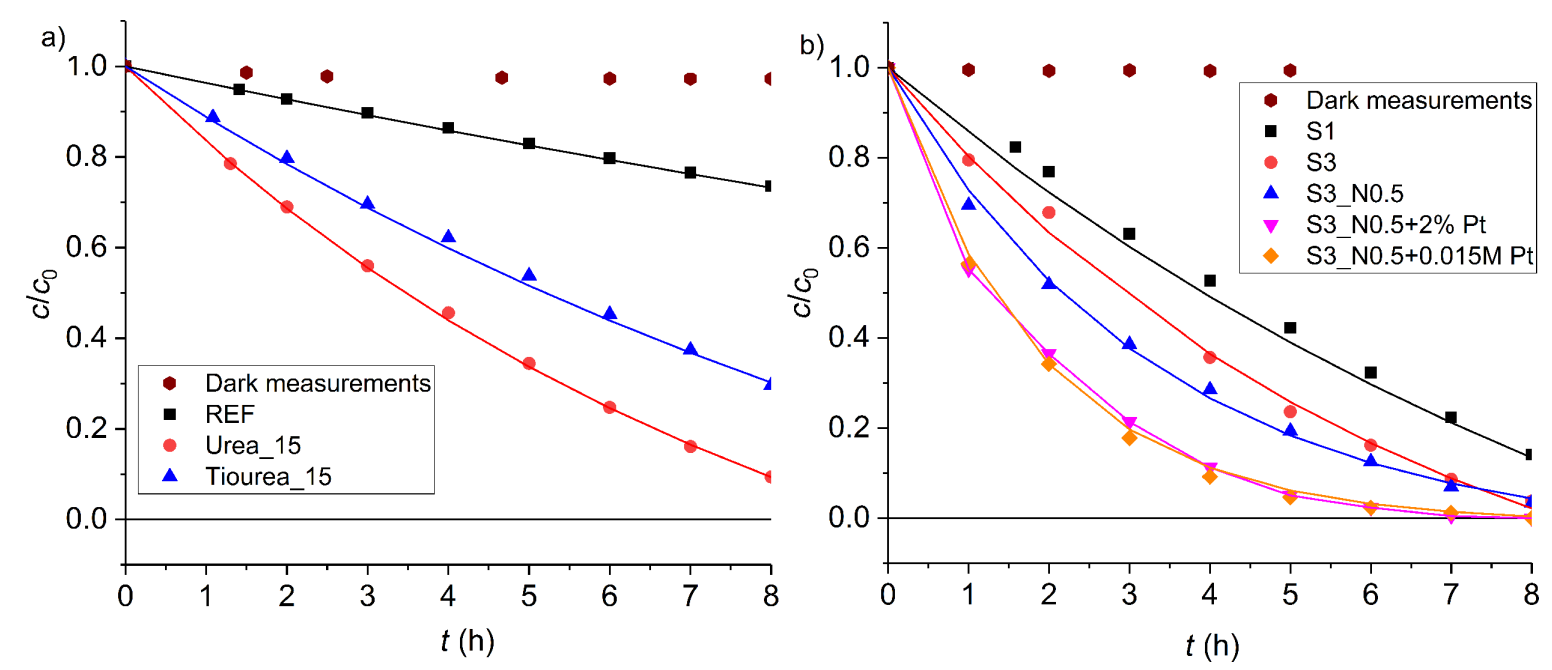

Figure 7: Photocatalytic activity of different samples a) synthesized with $\mathrm{HCl}$; dark measurements performed for sample REF and b) synthesized with $\mathrm{H}_{2} \mathrm{SO}_{4}$; dark measurements performed for sample S3. 


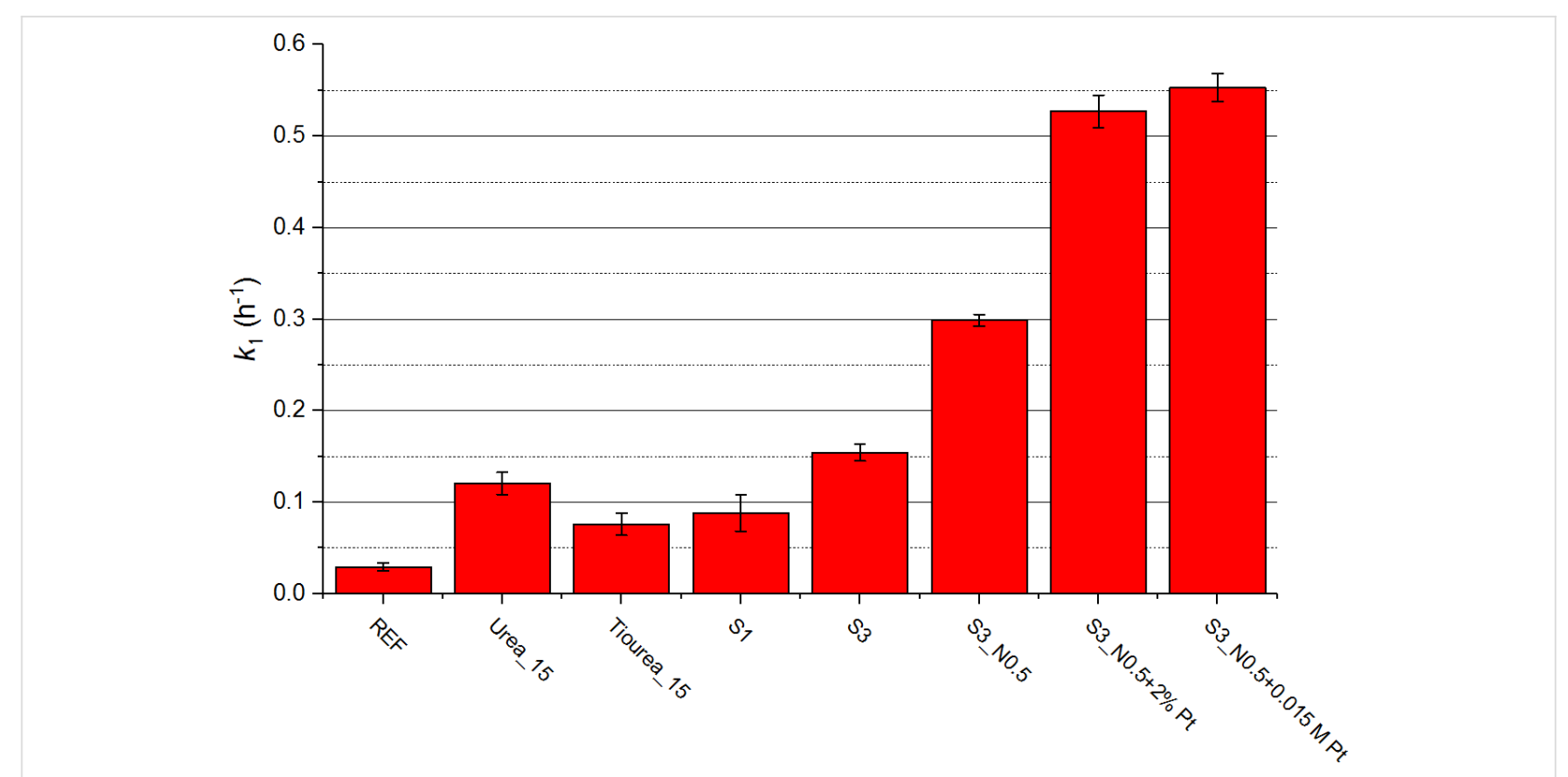

Figure 8: First-order rate constant for plasmocorinth B degradation for selected photocatalysts synthesized in this work.

whereby higher values correspond to higher photocatalytic activity of the sample.

By doping the reference sample (REF) with $\mathrm{N}$ (sample Urea_15) and S (sample Thiourea_15) (confirmed by XPS measurements), we were able to significantly decrease the band gap width of our material (3.44 eV for REF, $3.16 \mathrm{eV}$ for Urea_15 and $2.81 \mathrm{eV}$ for Thiourea_15) and consequently increase the degradation rate of PB $\left(k_{1}=0.029 \mathrm{~h}^{-1}\right.$ for REF, $0.12 \mathrm{~h}^{-1}$ for Urea_15 and $0.076 \mathrm{~h}^{-1}$ for Thiourea_15). However, the photocatalytic activity of these doped samples is limited by their relatively small specific surface area $\left(24.2 \mathrm{~m}^{2} / \mathrm{g}\right.$ for Urea_15 and $49.5 \mathrm{~m}^{2} / \mathrm{g}$ for Thiourea_15).

By substituting $\mathrm{HCl}$ with $\mathrm{H}_{2} \mathrm{SO}_{4}$ we were able to prepare more porous samples (surface area for S3 equals $80.2 \mathrm{~m}^{2} / \mathrm{g}$ ) with a narrower band gap relative to REF (band gap for $\mathrm{S} 3$ is $3.10 \mathrm{eV}$ ). We contribute the band gap narrowing to $\mathrm{H}_{2} \mathrm{SO}_{4}$ acting as a source of doped S (confirmed by XPS measurements). Furthermore, both acids also accelerate the dissolution of the precursor during sol-gel synthesis and act as sol stabilizers. Consequently, the $\mathrm{PB}$ degradation rate for $\mathrm{S} 3$ is higher than any other sample synthesized with $\mathrm{HCl}\left(k_{1}=0.15 \mathrm{~h}^{-1}\right.$ for $\left.\mathrm{S} 3\right)$.

Samples co-doped with N and S (e.g., S3_N0.5) have shown an increased photocatalytic activity under visible-light illumination $\left(k_{1}\right.$ for S3_N0.5 is $0.30 \mathrm{~h}^{-1}$ ). The band gap width for this sample was shown to be narrowed $(3.07 \mathrm{eV})$. Researchers attribute this to a synergetic effect between N $2 p$ and S $3 p$ orbitals, resulting in a hybridization of the two orbitals generated close to the valence band $[31,49]$. Furthermore, with the addition of $\mathrm{NH}_{4} \mathrm{NO}_{3}$, the sample became more porous (surface area of $84.5 \mathrm{~m}^{2} / \mathrm{g}$ ), which also explains the increased photocatalytic activity.

The band gap width and porosity have not changed significantly with the addition of $\mathrm{Pt}$ (band gap of $3.08 \mathrm{eV}$; surface area of $83.7 \mathrm{~m}^{2} / \mathrm{g}$ ). However, the PB degradation rate for these samples increased significantly, which can be explained by $\mathrm{Pt}$ acting as an efficient free electron trap, thereby reducing the undesirable electron-hole recombination while also improving the free-electron transfer to the adsorbed PB [25,50]. The best photocatalytic activity was observed for samples S3_N0.5+2\% $\mathrm{Pt}\left(k_{1}=0.53 \mathrm{~h}^{-1}\right)$ and S3_N0.5+0.015M Pt $\left(k_{1}=0.55 \mathrm{~h}^{-1}\right)$.

\section{Conclusion}

Nitrogen $(\mathrm{N})$, sulfur $(\mathrm{S})$ and platinum $(\mathrm{Pt})$-doped titania thin films were prepared by a particulate sol-gel synthesis. An organic polymer (hydroxypropyl cellulose; HPC) was added to increase the porosity of the samples. The prepared samples were then deposited onto glass substrates by dip-coating and thermally treated at 450 and $600{ }^{\circ} \mathrm{C}$. By substituting $\mathrm{HCl}$ with $\mathrm{H}_{2} \mathrm{SO}_{4}$ during the sol-gel synthesis, we were able to obtain samples doped with $\mathrm{S}$, which resulted in samples with a higher porosity, smaller crystallite size and a narrower band gap. All of this resulted in an increase in photocatalytic activity. Additionally, doping these samples with $\mathrm{N}$ slightly increased the surface area and narrowed the band gap, which consequentially increased its photocatalytic activity. The addition of Pt did not significantly affect the surface area or band gap width, but 
nevertheless increased the photocatalytic activity. We contribute this to Pt acting as a free-electron trap, thus reducing the recombination rate. To summarize, by doping our reference sample with $\mathrm{N}, \mathrm{S}$ or Pt we were able to significantly increase the photocatalytic activity of titania thin films under visiblelight illumination.

\section{Experimental}

The chemicals in this study were used as purchased: titanium tetrachloride $\left(\mathrm{TiCl}_{4},>98 \%\right)$ from Fluka; hydrochloric acid $(\mathrm{HCl}, 37 \%)$ from Fluka; sulfuric acid $\left(\mathrm{H}_{2} \mathrm{SO}_{4}, 97 \%\right)$ from Sigma-Aldrich; ethanol absolute; ammonium nitrate $\left(\mathrm{NH}_{4} \mathrm{NO}_{3}\right)$ from Zorka Šabac; hydroxypropyl cellulose (HPC, $M_{\mathrm{W}}=100.000 \mathrm{~g} / \mathrm{mol}$ ) from Sigma-Aldrich; plasmocorinth B (PB, dye content $\approx 60 \%$ ) from Sigma-Aldrich; thiourea (pro analysis) from Kemika and urea (98\%) from Acros Organics.

\section{Synthesis}

Titanium dioxide was prepared by a particulate sol-gel synthesis from titanium tetrachloride $\left(\mathrm{TiCl}_{4}\right)$ precursor. In the first step of the synthesis, the precursor was dissolved in water, which was previously acidified with different volumes of concentrated hydrochloric $(\mathrm{HCl})$ and $12 \mathrm{M}$ solution of sulfuric acid $\left(\mathrm{H}_{2} \mathrm{SO}_{4}\right)$. After the dissolution, different chemicals, which acted as sources of metal and nonmetal dopants (e.g., urea, thiourea, ammonium nitrate $-\mathrm{NH}_{4} \mathrm{NO}_{3}$, chloroplatinic acid $\mathrm{H}_{2} \mathrm{PtCl}_{6}$ ) and hydroxypropyl cellulose (HPC, an organic polymer, which increases the porosity of materials) were added. After deposition on glass substrates with dip-coating, the thin films were thermally treated in a muffle furnace at 450 (for the synthesis involving $\mathrm{HCl}$ ) and $600{ }^{\circ} \mathrm{C}$ (for the synthesis involving $\mathrm{H}_{2} \mathrm{SO}_{4}$ ) for 30 minutes to promote crystallization of $\mathrm{TiO}_{2}$.

Synthesis involving HCl (doping with urea and thiourea): $5.52 \mathrm{~mL}$ of $\mathrm{TiCl}_{4}$ was dissolved in a solution, containing $90 \mathrm{~mL}$ of distilled water and $18 \mathrm{~mL}$ of concentrated $\mathrm{HCl}$. After a day of stirring, $0.3 \mathrm{wt} \%$ (relative to the mass of the sol) of HPC was added. These samples were then doped with urea and thiourea. The undoped sample was named REF, whereas the doped samples were named Urea_5; Urea_10; Urea_15 and Urea_20. The numbers describe the molar percentage of the added dopant (relative to $\mathrm{TiO}_{2}$ ). The same process was performed for thiourea.

Synthesis involving $\mathrm{H}_{2} \mathrm{SO}_{4}$ (doping with $\mathrm{NH}_{4} \mathrm{NO}_{3}$ and $\mathbf{H}_{\mathbf{2}} \mathbf{P t C l}_{\mathbf{6}}$ ): $3.68 \mathrm{~mL}$ of $\mathrm{TiCl}_{4}$ were dissolved in a solution containing $60 \mathrm{~mL}$ of distilled water and different volumes of $12 \mathrm{M} \mathrm{H}_{2} \mathrm{SO}_{4}$. After one day of stirring, $0.3 \mathrm{wt} \%$ (relative to the mass of the solution) of HPC was added. Table 3 shows the sample names and corresponding volume of $12 \mathrm{M} \mathrm{H}_{2} \mathrm{SO}_{4}$ added.
Table 3: Sample names and corresponding volume of $12 \mathrm{M} \mathrm{H}_{2} \mathrm{SO}_{4}$ added.

\begin{tabular}{ll} 
Sample name & Added $\mathrm{H}_{2} \mathrm{SO}_{4}(\mathrm{~mL})$ \\
\hline $\mathrm{S} 1$ & 1.65 \\
$\mathrm{~S} 2$ & 3.30 \\
$\mathrm{~S} 3$ & 4.95 \\
$\mathrm{~S} 4$ & 6.60 \\
$\mathrm{~S} 5$ & 8.25
\end{tabular}

Sample $\mathrm{S} 3$ was then doped with different amounts of $\mathrm{NH}_{4} \mathrm{NO}_{3}$. The samples were named S3_N0.25, S3_N0.5, S3_N1, S3_N2, S3_N4 and S3_N6. The numbers next to $\mathrm{N}$ describe the molar percentages of added $\mathrm{NH}_{4} \mathrm{NO}_{3}$ (relative to $\mathrm{TiO}_{2}$ ).

Finally, we added $\mathrm{H}_{2} \mathrm{PtCl}_{6}$ to sample $\mathrm{S} 3$ _N0.5, in order to dope it with platinum. Some of the samples had platinum added directly into the sol (S3_N0.5+0.5\% Pt, S3_N0.5+1\% Pt and $\mathrm{S} 3 \_\mathrm{N} 0.5+2 \% \mathrm{Pt}$ ), where the percentage describes the molar percentage of added $\mathrm{Pt}$ (also relative to $\mathrm{TiO}_{2}$ ). To other samples (S3_N0.5+0.0025M Pt to S3_N0.5+0.02M Pt), platinum was added as the final layer in the form of chloroplatinic acid by dip-coating. The numbers refer to the molar concentration of deposited solution of $\mathrm{H}_{2} \mathrm{PtCl}_{6}$.

For XRD and XPS characterization, thin films were deposited onto silicon resins and thermally treated at 450 (for the synthesis involving $\mathrm{HCl}$ ) and $600{ }^{\circ} \mathrm{C}$ (for the synthesis involving $\mathrm{H}_{2} \mathrm{SO}_{4}$ ) for 30 minutes.

Powder analogues for BET and band gap analysis were prepared by drying the sols in air to produce xerogels. The xerogels were then thermally treated in a muffle furnace under the same conditions as the thin films.

\section{Characterization}

Simultaneous TGA-DSC-MS measurements were performed on a Mettler Toledo TGA/DSC1 instrument, coupled to a Pfeiffer Vacuum ThermoStar mass spectrometer. The samples were placed into Pt crucibles and heated from 25 to $800^{\circ} \mathrm{C}$ at a heating rate of $10^{\circ} \mathrm{C} / \mathrm{min}$.

XRD patterns were measured with a Siemens D5000 instrument in the $2 \theta$ range of $23-32^{\circ}$. The average crystallite sizes were calculated using Scherrer's equation.

The BET specific surface area and pore size distribution of the powders were determined by measuring the nitrogen adsorption-desorption isotherms with a Tristar 3000, Micromeritics (USA) instrument. The measurements were performed at $-196^{\circ} \mathrm{C}(77 \mathrm{~K})$. The samples were outgassed under vacuum for 
$16 \mathrm{~h}$ at $110^{\circ} \mathrm{C}(383 \mathrm{~K})$. The mass of the samples in the analyzer was $\approx 0.1 \mathrm{~g}$. The specific surface area was calculated from the adsorption measurements in the relative pressure $\left(p / p_{0}\right)$ range of $0.05-0.25$.

XPS spectra were recorded on a Perkin Elmer $\varphi$ 5600ci spectrometer at a pressure lower than $10^{-8}$ mbar, using a non-monochromatized Al K $\alpha$ excitation source $(h v=1486.6 \mathrm{eV})$. The BE shifts were corrected by assigning a value of $284.8 \mathrm{eV}$ to the C 1s line of adventitious carbon [51].

UV-vis absorption spectra were collected using an Agilent Cary $60 \mathrm{UV}-\mathrm{vis}$ spectrophotometer in the wavelength range $\lambda=400-800 \mathrm{~nm}$.

The morphology of thin films was examined using a field emission scanning electron microscope (FEI Inspect ${ }^{\mathrm{TM}}$ F50 and Ultra Plus Zeiss).

The band gap measurements were performed by measuring the reflectance of the samples using a UV-vis spectrophotometer (Evolution 600, Thermo Scientific), using the diffuse reflectance accessory (DRA-EV-600) integrating sphere. The measurements were performed in the range $240-840 \mathrm{~nm}$ a step of $1 \mathrm{~nm}$ and speed of $10 \mathrm{~nm} \mathrm{~min}{ }^{-1}$. The material Spectralon ${ }^{\circledR}$ was used as a reference. The band gap energy of the measured samples was determined using the Tauc's plot [52], based on the Kubelka-Munk theory [53,54].

\section{Photocatalytic activity tests}

The photocatalytic efficiency of the thin films was determined by measuring the degradation rate of plasmocorinth $\mathrm{B}$ (PB, $\gamma=12 \mathrm{mg} / \mathrm{L}$ ). The photocatalytic activity of the prepared thin films was tested in a home-made photoreactor, fitted with six $15 \mathrm{~W}$ Lumilux de Luxe daylight lamps. The thin films with an average area of $96 \mathrm{~cm}^{2}$ were immersed into a batch reactor, which was filled with $70 \mathrm{~mL}$ of dye solution and was purged with oxygen (flow rate $100 \mathrm{~mL} / \mathrm{min}$ ). The activity of the thin films was determined by measuring the absorption spectra of PB (absorption maximum at $\approx 527 \mathrm{~nm}$ ) after different durations of illumination with visible light. The concentration of the dye was calculated using the Beer-Lambert law.

\section{Acknowledgements}

The authors acknowledge the financial support from the Slovenian Research Agency (research core funding No. P1-0134), ACTION post-doc fellowship, the HERALD STSM - MP1402 action and the Ministry of Education, Science and Technological Development of the Republic of Serbia (Project number: III 45008). The authors also kindly acknowledge Mojca Opresnik from the National Institute of Chemistry,
Department of Inorganic Chemistry and Technology for BET measurements and Žiga Medoš from the Faculty of Chemistry and Chemical Technology for help with computer modelling.

\section{ORCID ${ }^{\circledR}$ iDs}

Bojan Miljević - https://orcid.org/0000-0002-0773-7115

\section{References}

1. Fröschl, T.; Hörmann, U.; Kubiak, P.; Kučerová, G.; Pfanzelt, M.; Weiss, C. K.; Behm, R. J.; Hüsing, N.; Kaiser, U.; Landfester, K.; Wohlfahrt-Mehrens, M. Chem. Soc. Rev. 2012, 41, 5313. doi:10.1039/c2cs35013k

2. Fitra, M.; Daut, I.; Irwanto, M.; Gomesh, N.; Irwan, Y. M. Energy Procedia 2013, 36, 278-286. doi:10.1016/j.egypro.2013.07.032

3. Hsu, W. P.; Yu, R.; Matijević, E. J. Colloid Interface Sci. 1993, 156, 56-65. doi:10.1006/jcis.1993.1080

4. Rozman, M.; Cerar, J.; Lukšič, M.; Uršič, M.; Mourtzikou, A.; Spreizer, H.; Škofic, I.; Stathatos, E. Electrochim. Acta 2017, 238, 278-287. doi:10.1016/j.electacta.2017.04.030

5. Schubert, M. M.; Plzak, V.; Garche, J.; Behm, R. J. Catal. Lett. 2001, 76, 143-150. doi:10.1023/A:1012365710979

6. Salaeh, S.; Juretic Perisic, D.; Biosic, M.; Kusic, H.; Babic, S.; Lavrencic Stangar, U.; Dionysiou, D. D.; Loncaric Bozic, A. Chem. Eng. J. 2016, 304, 289-302. doi:10.1016/j.cej.2016.06.083

7. Gaya, U. I.; Abdullah, A. H. J. Photochem. Photobiol., C: Photochem. Rev. 2008, 9, 1-12. doi:10.1016/j.jphotochemrev.2007.12.003

8. Wang, Y.; He, Y.; Lai, Q.; Fan, M. J. Environ. Sci. 2014, 26, 2139-2177. doi:10.1016/j.jes.2014.09.023

9. Haider, A. J.; AL-Anbari, R. H.; Kadhim, G. R.; Salame, C. T. Energy Procedia 2017, 119, 332-345. doi:10.1016/j.egypro.2017.07.117

10. Pan, J. H.; Dou, H.; Xiong, Z.; Xu, C.; Ma, J.; Zhao, X. S. J. Mater. Chem. 2010, 20, 4512. doi:10.1039/b925523k

11. Natoli, A.; Cabeza, A.; De La Torre, A. G.; Aranda, M. A. G.; Santacruz, I. J. Am. Ceram. Soc. 2012, 95, 502-508. doi:10.1111/j.1551-2916.2011.04883.x

12. Ao, C. H.; Lee, S. C. Chem. Eng. Sci. 2005, 60, 103-109. doi:10.1016/j.ces.2004.01.073

13. Wang, X.; Yu, J. C.; Ho, C.; Hou, Y.; Fu, X. Langmuir 2005, 21, 2552-2559. doi:10.1021/la047979c

14. Černigoj, U.; Lavrenčič Štangar, U.; Ribič, P.; Trebše, P. Acta Chim. Slov. 2006, 53, 29-35.

15. Samokhvalov, A. Renewable Sustainable Energy Rev. 2017, 72, 981-1000. doi:10.1016/j.rser.2017.01.024

16. Zita, J.; Krýsa, J.; Černigoj, U.; Lavrenčič-Štangar, U.; Jirkovský, J.; Rathouský, J. Catal. Today 2011, 161, 29-34. doi:10.1016/j.cattod.2010.11.084

17. Klimova, T.; Carmona, E.; Ramirez, J. J. Mater. Sci. 1998, 33, 1981-1990. doi:10.1023/A:1004386212175

18. Rutar, M.; Rozman, N.; Pregelj, M.; Bittencourt, C.; Cerc Korošec, R.; Sever Škapin, A.; Mrzel, A.; Škapin, S. D.; Umek, P. Beilstein J. Nanotechnol. 2015, 6, 831-844. doi:10.3762/bjnano.6.86 19. Zhigo, Z.; Wang, C.-C.; Zakaria, R.; Ying, J. Y. J. Phys. Chem. B 1998, 102, 10871-10878. doi:10.1021/jp982948 
20. Pelaez, M.; Nolan, N. T.; Pillai, S. C.; Seery, M. K.; Falaras, P.; Kontos, A. G.; Dunlop, P. S. M.; Hamilton, J. W. J.; Byrne, J. A.; O'Shea, K.; Entezari, M. H.; Dionysiou, D. D. Appl. Catal., B: Environ. 2012, 125, 331-349. doi:10.1016/j.apcatb.2012.05.036

21. Banerjee, S.; Pillai, S. C.; Falaras, P.; O'Shea, K. E.; Byrne, J. A.; Dionysiou, D. D. J. Phys. Chem. Lett. 2014, 5, 2543-2554. doi:10.1021/jz501030x

22. Ohno, T.; Mitsui, T.; Matsumura, M. Chem. Lett. 2003, 32, 364-365. doi:10.1246/cl.2003.364

23. Vodišek, N.; Ramanujachary, K.; Brezová, V.; Lavrenčič Štangar, U. Catal. Today 2017, 287, 142-147. doi:10.1016/j.cattod.2016.12.026

24. Arabatzis, I. M.; Stergiopoulos, T.; Bernard, M. C.; Labou, D.; Neophytides, S. G.; Falaras, P. Appl. Catal., B: Environ. 2003, 42, 187-201. doi:10.1016/S0926-3373(02)00233-3

25. Zielińska-Jurek, A.; Hupka, J. Catal. Today 2014, 230, 181-187. doi:10.1016/j.cattod.2013.09.045

26. Molinari, R.; Lavorato, C.; Argurio, P. Chem. Eng. J. 2015, 274, 307-316. doi:10.1016/j.cej.2015.03.120

27. Yang, G.; Jiang, Z.; Shi, H.; Xiao, T.; Yan, Z. J. Mater. Chem. 2010, 20, 5301. doi:10.1039/c0jm00376j

28. Šauta Ogorevc, J.; Tratar Pirc, E.; Matoh, L.; Bukovec, P. Acta Chim. Slov. 2012, 59, 264-272.

29. Livraghi, S.; Pelaez, M.; Biedrzycki, J.; Corazzari, I.; Giamello, E.; Dionysiou, D. D. Catal. Today 2013, 209, 54-59. doi:10.1016/j.cattod.2012.12.020

30. Ho, W.; Yu, J. C.; Lee, S. J. Solid State Chem. 2006, 179, 1171-1176. doi:10.1016/j.jssc.2006.01.009

31. Periyat, P.; McCormack, D. E.; Hinder, S. J.; Pillai, S. C. J. Phys. Chem. C 2009, 113, 3246-3253. doi:10.1021/jp808444y

32. Mathis, J. E.; Lieffers, J. J.; Mitra, C.; Reboredo, F. A.; Bi, Z.; Bridges, C. A.; Kidder, M. K.; Paranthaman, M. P. Ceram. Int. 2016, 42 , 3556-3562. doi:10.1016/j.ceramint.2015.10.164

33. Fagan, R.; McCormack, D. E.; Dionysiou, D. D.; Pillai, S. C. Mater. Sci. Semicond. Process. 2016, 42, 2-14. doi:10.1016/j.mssp.2015.07.052

34. Wang, C.; Chen, Z.; Jin, H.; Cao, C.; Li, J.; Mi, Z. J. Mater. Chem. A 2014, 2, 17820-17827. doi:10.1039/C4TA04254A

35. Zaleska, A. Recent Pat. Eng. 2008, 2, 157-164. doi:10.2174/187221208786306289

36. Asahi, R.; Morikawa, T.; Ohwaki, T.; Aoki, K.; Taga, Y. Science 2001, 293, 269-271. doi:10.1126/science.1061051

37. Devi, L. G.; Kavitha, R. Mater. Chem. Phys. 2014, 143, 1300-1308. doi:10.1016/j.matchemphys.2013.11.038

38. Rehman, S.; Ullah, R.; Butt, A. M.; Gohar, N. D. J. Hazard. Mater. 2009, 170, 560-569. doi:10.1016/j.jhazmat.2009.05.064

39. Albrbar, A. J.; Djokić, V.; Bjelajac, A.; Kovač, J.; Ćirković, J.; Mitrić, M.; Janaćković, D.; Petrović, R. Ceram. Int. 2016, 42, 16718-16728. doi:10.1016/j.ceramint.2016.07.144

40. Chen, Z.; Ma, J.; Yang, K.; Feng, S.; Tan, W.; Tao, Y.; Mao, H.; Kong, Y. Synth. Met. 2017, 231, 51-57. doi:10.1016/j.synthmet.2017.06.020

41. Hosseingholi, M.; Pazouki, M.; Hosseinnia, A.; Aboutalebi, S. H. J. Phys. D: Appl. Phys. 2011, 44, 55402. doi:10.1088/0022-3727/44/5/055402

42. Blanco-Vega, M. P.; Guzmán-Mar, J. L.; Villanueva-Rodríguez, M.; Maya-Treviño, L.; Garza-Tovar, L. L.; Hernández-Ramírez, A.; Hinojosa-Reyes, L. Mater. Sci. Semicond. Process. 2017, 71, 275-282. doi:10.1016/j.mssp.2017.08.013
43. Hanaor, D. A. H.; Chironi, I.; Karatchevtseva, I.; Triani, G.; Sorrell, C. C. Adv. Appl. Ceram. 2012, 111, 149-158. doi:10.1179/1743676111Y.0000000059

44. Drumond Chequer, F. M.; de Oliveira, G. A. R.; Anastacio Ferraz, E. R.; Carvalho, J.; Boldrin Zanoni, M. V.; de Oliveir, D. P. Textile Dyes: Dyeing Process and Environmental Impact. In Eco-Friendly Textile Dyeing and Finishing; Günay, M., Ed. InTech: Zagreb, Croatia, 2013; pp 151-176. doi:10.5772/53659

45. Addamo, M.; Bellardita, M.; Di Paola, A.; Palmisano, L. Chem. Commun. 2006, 4943. doi:10.1039/b612172a

46. Moulder, J. F.; Sticle, W. F.; Sobol, P. E.; Bomben, K. D. Handbook of $X$-ray Photoelectron Spectroscopy, 1st ed.; Perkin Elmer Corporation: Eden Prairie, MN, U.S.A., 1992.

47. Shen, K.; Xue, X.; Wang, X.; Hu, X.; Tian, H.; Zheng, W. RSC Adv. 2017, 7, 23319-23327. doi:10.1039/C7RA01856H

48. Bittencourt, C.; Ewels, C.; Krasheninnikov, A. V. Beilstein J. Nanotechnol. 2015, 6, 1708-1711. doi:10.3762/bjnano.6.174

49. Wei, F.; Ni, L.; Cui, P. J. Hazard. Mater. 2008, 156, 135-140. doi:10.1016/j.jhazmat.2007.12.018

50. Giannakas, A. E.; Antonopoulou, M.; Papavasiliou, J.; Deligiannakis, Y.; Konstantinou, I. J. Photochem. Photobiol., A: Chem. 2017, 349, 25-35. doi:10.1016/j.jphotochem.2017.08.066

51. Briggs, D.; Seah, M. P. Practical Surface Analysis: Auger and X-ray Photoelectron Spectroscopy, 2nd ed.; John Wiley \& Sons: New York, NY, U.S.A., 1990.

52. Tauc, J. Mater. Res. Bull. 1968, 3, 37-46. doi:10.1016/0025-5408(68)90023-8

53. Kubelka, P.; Munk, F. Z. Tech. Phys. 1931, 12, 593-601.

54. Kubelka, P. J. Opt. Soc. Am. 1948, 38, 448. doi:10.1364/JOSA.38.000448

\section{License and Terms}

This is an Open Access article under the terms of the Creative Commons Attribution License (http://creativecommons.org/licenses/by/4.0), which permits unrestricted use, distribution, and reproduction in any medium, provided the original work is properly cited.

The license is subject to the Beilstein Journal of Nanotechnology terms and conditions: (https://www.beilstein-journals.org/bjnano)

The definitive version of this article is the electronic one which can be found at: doi:10.3762/bjnano.9.155 